\title{
QUALITY OF PLYWOODS OBTAINED FROM Melia azedarach COMBINED WITH Pinus taeda, PRODUCED WITH UREA- FORMALDEHYDE AND PHENOL-FORMALDEHYDE RESINS
}

\author{
Setsuo Iwakiri ${ }^{1}$, Rosilani Trianoski ${ }^{1}$, Vinicius Gomes de Castro $^{2}$, Carlos Frederico Alice Parchen ${ }^{3}$, \\ Roberto Daniel de Araujo ${ }^{4}$ \\ ${ }^{1}$ Forest Eng., Dr., Engineering and Forest Technology Department, UFPR, Curitiba, PR, Brasil - setsuo@ufpr.br; rosilani @ufpr.br \\ ${ }^{2}$ Forest Eng., M.Sc., Doctoral Candidate, Postgraduate in Forest Engineering, UFPR, Curitiba, PR, Brasil - vinnie.castro@ gmail.com \\ ${ }^{3}$ Civil Eng., Dr., Civil Engineering Department, UFPR, Curitiba, PR, Brasil - parchen@ufpr.br \\ ${ }^{4}$ Architect, M.Sc., Doctoral Candidate, Postgraduate in Forest Engineering, UFPR, Curitiba, PR, Brasil - rdaniel@inpa.gov.br
}

Received for publication: 13/02/2013 - Accepted for publication: 22/10/2013

\begin{abstract}
This study was developed to evaluate the quality of plywood produced from Melia azedarach in combination with Pinus taeda, glued with urea-formaldehyde resin (UF) and phenol formaldehyde (PF). Panels were produced using five veneers of Melia azedarach only, five veneers of Pinus taeda and also with faces made of Melia azedarach and core with Pinus taeda. The panels were evaluated by glue line shear tests and by static bending in parallel and perpendicular directions. The higher contents of extractives in Melia azedarach wood did not reduce the glue line shear strength between the layers. For both UF and PF glues, panels produced with veneers of Melia azedarach showed better results on static bending and glue line shear tests. The results indicate great potential of Melia azedarach wood in plywood production, both for internal use (UF), and for external use (PF).

Keywords: Cinamomo; wood veneer; glue line.

Resumo
Qualidade de painéis compensados de Melia azedarach em combinação com Pinus taeda produzidos com resina uréia-formaldeído e fenol-formaldeído. O objetivo deste trabalho foi avaliar a qualidade de painéis compensados de Melia azedarach em combinação com Pinus taeda, produzidos com resina ureia-formaldeído (UF) e fenol-formaldeído (FF). Foram produzidos painéis com todas as cinco lâminas de Melia azedarach e de Pinus taeda, e capas de Melia azedarach e miolo de Pinus taeda. Os painéis foram avaliados por meio de ensaios de cisalhamento da linha de cola e flexão estática paralela e perpendicular. Maiores teores de extrativos presentes na madeira de Melia azedarach não prejudicaram a resistência da linha de cola entre as lâminas. Tanto para a colagem uréica, quanto para a fenólica, os painéis produzidos com lâminas de Melia azedarach apresentaram melhores resultados nos ensaios de flexão estática e de cisalhamento da linha de cola. Os resultados obtidos indicam grande potencial da madeira de Melia azedarach para produção de painéis compensados, tanto para uso interior (UF), quanto para uso exterior (FF).

Palavras-chave: Cinamomo; lâminas de madeira; linha de cola.
\end{abstract}

\section{INTRODUCTION}

Several studies have been performed in Brazil on fast growing forest species that are used for the production of wood veneers and plywood, with the intention to increase the range of species as alternatives to Pinus, which is the main raw material used by plywood industries.

Besides the species belonging to the genus Eucalyptus, various researchers studied the behavior of other species, suitable for veneers and plywood production. Pinto (2001) evaluated the lamination yield and plywood quality of Criptomeria japônica; Bortoleto Jr. and Belini (2002) studied the behavior of Schizolobium parayba wood in plywood production; and, Iwakiri et al. (2011) evaluated the quality of plywood produced with veneers made of Schizolobium amazonicum. Despite the low wood density of 
these species, researchers recognized indicators of their potential for the use in veneers and plywood production.

Melia azedarach L. is a medium sized species and belongs to the Meliaceae family. It is native to Asia and diffuse in India, Pakistan, Sri Lanka, Thailand, Laos, Vietnam and Brazil, being extensively cultivated in Asia and in the southern regions of Latin America (BOBADILLA, 2004). It grows in regions up to $2000 \mathrm{~m}$ high, average annual temperature of $18{ }^{\circ} \mathrm{C}$ and annual rainfall from 600 to $2.000 \mathrm{~mm}$ (VIVIAN, 2005). In Brazil this species is widely cultivated, specifically in the South Region. Melia azedarach L. presents high edapho-climatic adaptation capability and a good wood quality which justifies the high investments for the production of raw material to supply the furniture industry, small carpenter shops and also the small private use of families in rural areas (TRIANOSKI, 2010). Wood characteristics of Melia azedarach are similar to Cedar, both plants are known for producing an excellent quality wood and for presenting a similar chemical composition (MARTINEZ, 2002).

Limitations related to the low wood density of fast growing species coming from planted forests, and the small diameter of trees, can be minimized by the use of gluing technologies for the production of reconstituted wood products like veneers and plywood. Bendsten (1978) affirms that, to be successful using wood produced in planted forests, traditional concepts must be modified and adapted to the characteristics of the available raw material.

In the production of plywood, the chemical and physical aspects involved in the veneers gluing process are extremely important, because the quality of panels is strongly depending on them (MARRA, 1992). The type of resin used in the gluing process depends on where the panel will be installed. Ureaformaldehyde resin is used for internal environments while phenol-formaldehyde is used for external applications.

Baldwin (1995) and Sellers (1993) affirm that the density of wood is an important factor in the definition of the gluing parameters because of the interactions between wood porosity and glue absorption when the adhesive bond is formed between the veneers. According to Marra (1992), low density woods will absorb a bigger quantity of glue, due to higher porosity, such that glue viscosity must be increased to avoid the formation of an "hungry" glue line.

Other factors like $\mathrm{pH}$ and extractive components of the wood are also important since they can interfere on glue curing time during the pressing process of the panels in the hot press. According to Marra (1992), species with a very low pH accelerate the polymerization process of the urea-formaldehyde resin and this can cause the anticipation of glue line curing, reducing the adhesive bond strength. Baldwin (1995) affirms that some extractive components found in the veneers may hinder the vaporization process and its migration from a glue line to another, and also prevent migration of the glue lines to the borders of the panels, condition that leads to liberation of vapors in the external environment. If this process is very slow it will lead to an increase of the internal pressure, resulting in a "burst" when the press is opened, causing delamination of the panel.

Considering the importance of studies on rapid growth species coming from planted forests for the production of veneers and plywood, this study aimed to evaluate the possibility to use Melia azedarach wood, combined with Pinus taeda wood, for the production of plywood glued with ureaformaldehyde and phenol-formaldehyde resins.

\section{MATERIALS AND METHODS}

Wood veneers from the species Melia azedarach and Pinus taeda were used in this study. Wood from Melia azedarach was obtained from experimental plantations located in the municipality of Corupá - SC 18,5 years old. Pinus taeda wood was collected in forest plantations, 18 years old, located in the municipality of Ventania - PR.

To assess the physical and chemical properties of wood, after selection and chopping of the trees (5), duplicated samples were obtained from positions corresponding to $0 \%, 25 \%, 50 \%, 75 \%$ and $100 \%$ of the commercial height. The basic specific wood mass was determined according to procedures described in the Norm COPANT 461/1972. Chemical properties were determined according to the norms TAPPI, with evaluation of the soluble components in cold and hot water (TAPPI 207:1999), in sodium hydroxide - NaOH (TAPPI 212:2002), the extractive components soluble in ethanol toluene (TAPPI 280:1999), total extractive components (TAPPI 204:1988) and pH (TAPPI 252:2002). 
Logs of the studied species were laminated to obtain veneers with a nominal thickness of $2 \mathrm{~mm}$, which were lately dried and cut to obtain the dimensions 500 x $500 \mathrm{~mm}$. Plywood panels were produced with the above specified dimensions and with a nominal thickness of $10 \mathrm{~mm}$ (5 veneers), using ureaformaldehyde resin (UF) with $61,8 \%$ solid content, $\mathrm{pH}$ equal to 7,8 and Brokfield viscosity of $867,8 \mathrm{cP}$. The phenol-formaldehyde resin (PF) was also used, with $48,5 \%$ solid content, pH equal to 12,5 and Brokfield viscosity of $543,2 \mathrm{cP}$.

For the gluing process with UF resin, veneers were dried to obtain an average humidity of $8 \%$. Glue was prepared with 100 parts of UF resin, 20 parts of wheat flour, 20 parts of water and 1.5 parts of catalyst. Glue grammage was $360 \mathrm{~g} / \mathrm{m}^{2}$ (double line) and pressing was performed with specific pressure of $10 \mathrm{kgf} / \mathrm{cm}^{2}$ at $140{ }^{\circ} \mathrm{C}$ temperature and 10 minutes pressing time.

For the gluing process with FF resin, veneers were dried to obtain an average humidity of $8 \%$. Glue was prepared with 100 parts of FF resin, 5 parts of wheat flour, 5 parts of water and 5 parts of coconut bark. Glue grammage was $360 \mathrm{~g} / \mathrm{m}^{2}$ (double line) and panels were pressed with a specific pressure of $10 \mathrm{kgf} / \mathrm{cm}^{2}$ at $140{ }^{\circ} \mathrm{C}$ temperature and 10 minutes pressing time.

Experiment was designed with 6 treatments with 2 replications per treatment, with variations of veneers composition and type of resin, as per table 1

Table 1. Experimental design.

Tabela 1. Delineamento experimental.

\begin{tabular}{lcc}
\hline Treatment & Composition & Resin \\
\hline 1 & MMMMM $^{1}$ & UF \\
2 & MPPPM $^{2}$ & UF \\
3 & PPPPP $^{3}$ & UF \\
4 & MMMMM $^{1}$ & FF \\
5 & MPPPM $^{2}$ & FF \\
6 & PPPPP $^{3}$ & FF \\
\hline${ }^{1}$ Plywood structure made with $100 \%$ Melia azedarach veneers; ${ }^{2}$ Plywood structure with external Melia azedarach veneers and \\
Pinus taeda internally; ${ }^{3}$ Plywood structure with $100 \%$ Pinus taeda veneers; UF: Urea-Formaldehyde; FF: Phenol-Formaldehyde.
\end{tabular}

After the pressing process and subsequent cooling to room temperature and humidity $\left(20 \pm 2{ }^{\circ} \mathrm{C}\right.$ and $65 \pm 5 \%$ ), panels were sectioned to obtain samples in order to determine the modulus of elasticity (MOE),and the modulus of rupture (MOR) in static bending test (EN:310:2002), along with resistance of the glue line to shear forces (EN 314-1:2004 and EN 314-2:2002).

Results obtained from physical and chemical assays of wood and from mechanical assays of the plywood panels were submitted to statistical analysis with Grubbs, Shaphiro Wilks, Bartlett and ANOVA tests. Once rejected the null hypothesis, comparison of means was performed through Tukey range test. All statistical tests were performed using the Program Statgraphics Centurion XVI, at 95\% of probability.

\section{RESULTS AND DISCUSSION}

\section{Chemical and physical properties of wood}

In table 2 are presented the results of the basic specific mass and chemical properties obtained from the Melia azedarach and Pinus taed woods.

Basic specific mass of Melia azedarach wood was $0.488 \mathrm{~g} / \mathrm{cm}^{3}$ and was not statistically different from the mean value of Pinus taeda, which value was equal to $0.485 \mathrm{~g} / \mathrm{cm}^{3}$. With regard to the chemical and physical properties, Melia azedarach presented mean values of the extractive components soluble in cold water, in $\mathrm{NaOH}$, total extractives and $\mathrm{pH}$ that were statistically higher when compared to the values of Pinus taeda. There were not significant differences for the extractive components soluble in hot water and in ethanol toluene. As a reference, Castro (2002), studying wood of Eucalyptus grandis, found that the total extractive components were 4.08. Trianoski (2002) found that in five tropical pinus species $(P$. caribaea, $P$. chiapensis, $P$. maximinoi, $P$. oocarpa and $P$. tecunumanii) the total extractive components were respectively $8.01 ; 8.82 ; 4.76 ; 7.93 ; 7.16$. Thus, all the species of tropical pinus studied showed higher total extractive components content when compared to Melia azedarach wood. 
Table 2. Mean values results of the physical and chemicals properties of wood from Melia azedarach and Pinus taeda.

Tabela 2. Resultados médios das propriedades física e químicas das madeiras de Melia azedarach e Pinus taeda.

\begin{tabular}{lcc}
\hline Property & Melia azedarach & Pinus taeda \\
\hline Basic specific mass $\left(\mathrm{g} / \mathrm{cm}^{3}\right)$ & $0.488 \mathrm{a}(4.05)$ & $0.485 \mathrm{a}(6.08)$ \\
Solubility in cold water $(\%)$ & $2.93 \mathrm{a}(3.83)$ & $2.02 \mathrm{~b}(3.25)$ \\
Solubility in hot water $(\%)$ & $3.85 \mathrm{a}(3.61)$ & $2.90 \mathrm{a}(3.22)$ \\
Solubility in $\mathrm{NaOH}(\%)$ & $12.26 \mathrm{a}(1.25)$ & $9.31 \mathrm{~b}(3.34)$ \\
Extractive components in ethanol toluene $(\%)$ & $2.95 \mathrm{a}(2.85)$ & $2.86 \mathrm{a}(6.67)$ \\
Total extractive components $(\%)$ & $4.41 \mathrm{a}(0.87)$ & $3.34 \mathrm{~b}(6.18)$ \\
$\mathrm{pH}$ & $5.46 \mathrm{a}(1.03)$ & $4.68 \mathrm{~b}(1.42$ \\
\hline
\end{tabular}

Means followed by the same letter in the same line are statistically equal according to the Tukey range test at $95 \%$ of probability; Values between brackets are referred to the coefficient of variation.

\section{Mechanical properties of the plywood panels}

Static bending

Results of static bending tests on Melia azedarach and Pinus taeda plywood panels, in the parallel and perpendicular directions, are displayed in table $3 .$.

Table 3. Mean values of modulus of rupture and modulus of elasticity in the parallel and perpendicular directions of plywood.

Tabela 3. Resultados médios de módulo de ruptura e módulo de elasticidade na direção paralela e perpendicular dos painéis compensados.

\begin{tabular}{lcccc}
\hline \multirow{2}{*}{ Treatment } & \multicolumn{2}{c}{ Parallel } & \multicolumn{2}{c}{ Perpendicular } \\
\cline { 2 - 5 } & $\begin{array}{c}\text { MOR } \\
\text { (MPa) }\end{array}$ & $\begin{array}{c}\text { MOE } \\
\text { (MPa) }\end{array}$ & $\begin{array}{c}\text { MOR } \\
\text { (MPa) }\end{array}$ & $\begin{array}{c}\text { MOE } \\
\text { (MPa) }\end{array}$ \\
\hline \multirow{2}{*}{1 - UF } & $71.62 \mathrm{a}$ & $7,881.17 \mathrm{a}$ & $35.81 \mathrm{a}$ & $2,483.82 \mathrm{a}$ \\
& $(13.70)$ & $(5,27)$ & $(11.10)$ & $(5.40)$ \\
2 - UF & $59.74 \mathrm{~b}$ & $6,014.35 \mathrm{~b}$ & $35.10 \mathrm{a}$ & $2,937.90 \mathrm{a}$ \\
& $(11.91)$ & $(7.00)$ & $(18.37)$ & $(20.56)$ \\
3 - UF & $46.29 \mathrm{c}$ & $5,081.21 \mathrm{~b}$ & $28.47 \mathrm{a}$ & $1,641.08 \mathrm{~b}$ \\
& $(13.52)$ & $(20.72)$ & $(15.91)$ & $(36.30)$ \\
\hline \multirow{2}{*}{4 - FF } & $75.61 \mathrm{a}$ & $7,523.13 \mathrm{a}$ & $37.66 \mathrm{ab}$ & $2,668.13 \mathrm{a}$ \\
& $(8.04)$ & $(6.97)$ & $(24.21)$ & $(16.01)$ \\
5 - FF & $66.67 \mathrm{ab}$ & $6,337.22 \mathrm{~b}$ & $40.17 \mathrm{a}$ & $2,612.60 \mathrm{a}$ \\
& $(14.04)$ & $(6.37)$ & $(20.98)$ & $(17.46$ \\
6 - FF & $56.24 \mathrm{~b}$ & $4,874.04 \mathrm{c}$ & $26.71 \mathrm{~b}$ & $1,578.80 \mathrm{~b}$ \\
& $(21.53)$ & $(12.26)$ & $(15.66)$ & $(30.34)$ \\
\hline
\end{tabular}

UF: Urea-formaldehyde; FF: Phenol-formaldehyde; MOR: Module of Rupture; MOE: Module of Elasticity; Means followed by the same letter in the same column and between the same type of resin are statistically equal according to the Tukey range test at $95 \%$ of probability; Values between brackets are referred to the coefficient of variation.

Plywood panels UF type, entirely produced with Melia azedarach veneers, presented parallel MOR and MOE mean values that were statistically higher than the values of the panels produced with Melia azedarach veneers on the external faces and with Pinus taeda veneers internally. Panels produced with external veneers of Melia azedarach presented higher MOR values than the ones entirely produced with Pinus taeda. As regards the perpendicular MOR values were not statistically different between panels produced with different veneers compositions. Regarding the perpendicular MOE, panels entirely produced with Pinus taeda veneers presented statistically lower mean value than the panels made with Melia azedarach veneers.

Comparative analysis with reference values reported in literature demonstrated that panels made with Melia azedarach and Pinus taeda presented parallel static bending results higher than the ones obtained by Stella (2009), who studied plywood made with "Paricá", reporting values varying from 4.932 to $5.402 \mathrm{MPa}$ for MOE and from 29 to $35 \mathrm{MPa}$ for MOR. Same for perpendicular MOE and MOR, with values that varied respectively from 1.554 to $1.738 \mathrm{MPa}$ and from 16 to $17 \mathrm{MPa}$ 
Plywood panels type FF entirely made with Melia azedarach veneers presented a mean parallel MOR value statistically equal to panels made with Melia azedarach veneers on the external faces and and an higher value when compared to plywood entirely made with Pinus taeda veneers. As regards the parallel MOE, panels made only with Melia azedarach veneers presented statistically superior mean values when compared to panels made with Melia azedarach on the external faces and to panels entirely made with $P$. taeda veneers. Panels made with Melia azedarach on the external faces presented statistically higher mean values when compared to panels entirely made with $P$. taeda veneers. As regards the perpendicular MOR, panels made with Melia azedarach on the external faces presented statistically equal mean values when compared to panels entirely made with Melia azedarach and superior values when compared to panels entirely made with Pinus taeda. As regards the perpendicular MOE, panels entirely produced with Melia azedarach, and the ones produced with veneers of the same species on the external faces, presented mean values statistically equal between them and superior when compared to panels entirely made with Pinus taeda.

As regards the results reported in literature, Iwakiri et al.(2011), studying phenolic plywood of Schizolobium amazonicum (Paricá), verified parallel and perpendicular MOR values respectively from 21 to $32 \mathrm{MPa}$ and from 12 to $17 \mathrm{MPa}$. Parallel and perpendicular MOE for the same species was verified to be respectively from 3.965 to $5.279 \mathrm{MPa}$ and from 1.165 to $1.623 \mathrm{MPa}$. Therefore, the results obtained in this study for pure and mixed Melia azedarach and Pinus taeda plywood were far superior to Paricá plywood. However, with regards to mixed Eucalyptus dunnii and Pinus taeda plywood, produced by Jaeger and Ziger (2007), results obtained in this study were inferior. The mentioned authors reported mean parallel and perpendicular MOE values respectively of 9.845 and $4.926 \mathrm{MPa}$, with parallel and perpendicular mean MOE values respectively of 57 and $35 \mathrm{MPa}$.

Resistance of glue line to shear forces

Table 4 presents the results of glue line shear strength assays for plywood panels made with Melia azedarach and Pinus taeda, glued with UF resin.

Mean values of glue line shear stresses in the UF panels varied from 1.53 to $2.25 \mathrm{MPa}$ for the dry test and from 0.97 to $1.97 \mathrm{MPa}$ for the test in cold water. In both types of test, panels entirely made with Melia azedarach presented statistically superior mean value when compared to panels entirely made with Pinus taeda and to the ones made with external faces of Melia azedarach and Pinus taeda inside. Therefore it is possible to affirm that glue binding between Melia azedarach veneers resulted in an higher glue line resistance when compared to bindings between Pinus taeda veneers. Both for Melia azedarach and for Pinus taeda veneers, percentages of wood failures in the glue line were very low.

Table 4. Mean values of glue line shear strength of plywood glued with UF resin.

Tabela 4. Resultados médios da resistência da linha de cola ao cisalhamento dos painéis compensados colados com resina UF.

\begin{tabular}{|c|c|c|c|c|}
\hline \multirow{3}{*}{ Treatment } & \multicolumn{4}{|c|}{ Pre-treatment } \\
\hline & \multicolumn{2}{|c|}{ Dry } & \multicolumn{2}{|c|}{24 hours in cold water } \\
\hline & $\begin{array}{l}\text { Mean } \\
\text { (MPa) }\end{array}$ & $\begin{array}{c}\text { Failure } \\
(\%)\end{array}$ & $\begin{array}{l}\text { Mean } \\
\text { (MPa) }\end{array}$ & $\begin{array}{c}\text { Failure } \\
(\%)\end{array}$ \\
\hline 1 - UF & $\begin{array}{c}2.25 \mathrm{a} \\
(14.67)\end{array}$ & 19.50 & $\begin{array}{c}1.97 \mathrm{a} \\
(13.61)\end{array}$ & 9.00 \\
\hline 2 - UF & $\begin{array}{l}1.53 \mathrm{~b} \\
(17.24)\end{array}$ & 20.51 & $\begin{array}{c}0.98 \mathrm{~b} \\
(19.91)\end{array}$ & 20.79 \\
\hline $3-U F$ & $\begin{array}{c}1.55 \mathrm{~b} \\
(18.54)\end{array}$ & 24.25 & $\begin{array}{c}1.08 \mathrm{~b} \\
(23.05)\end{array}$ & 12.75 \\
\hline
\end{tabular}

Means followed by the same letter in the same column are statistically equal according to the Tukey range test at $95 \%$ of probability; Values between brackets are referred to the coefficient of variation.

Table 5 presents the results of glue line shear strength assays for plywood panels made with Melia azedarach and Pinus taeda, glued with FF resin. 
Table 5. Mean values of glue line shear strength of plywood glued with FF resin.

Tabela 5. Resultados médios da resistência da linha de cola ao cisalhamento dos painéis compensados colados com resina FF.

\begin{tabular}{|c|c|c|c|c|c|c|}
\hline \multirow{3}{*}{ Treatment } & \multicolumn{6}{|c|}{ Pre-treatment } \\
\hline & \multicolumn{2}{|c|}{ Dry } & \multicolumn{2}{|c|}{ Boiling cycle } & \multicolumn{2}{|c|}{72 boiling hours } \\
\hline & $\begin{array}{l}\text { Mean } \\
(\mathrm{MPa})\end{array}$ & $\begin{array}{c}\text { Failure } \\
(\%)\end{array}$ & $\begin{array}{l}\text { Mean } \\
\text { (MPa) }\end{array}$ & $\begin{array}{c}\text { Failure } \\
(\%)\end{array}$ & $\begin{array}{l}\text { Mean } \\
\text { (MPa) }\end{array}$ & $\begin{array}{c}\text { Failure } \\
(\%)\end{array}$ \\
\hline $4-\mathrm{FF}$ & $\begin{array}{c}3.06 \mathrm{a} \\
(13.80)\end{array}$ & 33.33 & $\begin{array}{l}2.00 \mathrm{a} \\
(8.22)\end{array}$ & 7.92 & $\begin{array}{c}1,64 \mathrm{a} \\
(13.34)\end{array}$ & 9.17 \\
\hline $5-\mathrm{FF}$ & $\begin{array}{c}2.32 \mathrm{~b} \\
(16.84)\end{array}$ & 45.00 & $\begin{array}{c}1.38 \mathrm{~b} \\
(23.97)\end{array}$ & 51.25 & $\begin{array}{c}1.27 \mathrm{~b} \\
(19.23)\end{array}$ & 63.75 \\
\hline $6-\mathrm{FF}$ & $\begin{array}{c}2.39 \mathrm{~b} \\
(15.37)\end{array}$ & 54.17 & $\begin{array}{c}1.13 \mathrm{c} \\
(16.62)\end{array}$ & 54.17 & $\begin{array}{c}1.15 \mathrm{~b} \\
(13.91)\end{array}$ & 50.00 \\
\hline
\end{tabular}

Means followed by the same letter in the same column are statistically equal according to the Tukey range test at $95 \%$ of probability; Values between brackets are referred to the coefficient of variation.

Mean values of the glue line shear stresses obtained with FF panels varied from 2.32 to 3.06 MPa in the dry test, from 1.13 to $2.00 \mathrm{MPa}$ in the boiling cycle test and from 1.15 to 1.64 for the 72 hours boiling test. In the three test methods, panels entirely produced with Melia azedarach veneers presented statistically superior mean value when compared to panels entirely produced with Pinus taeda veneers and to mixed panels produced with Melia azedarach faces with internal Pinus taeda veneers. Therefore it is possible to affirm that glue bindings between Melia azedarach veneers resulted in an higher resistance of the glue line when compared to bindings of Pinus taeda veneers

Evaluations of wood failures percentage showed best results for the glue bindings of Pinus taeda veneers when compared to Melia azedarach, according to values obtained in treatments T5 and T6.

Comparing the results reported in literature, Iwakiri et al. (2002), studying plywood panels made with Pinus taeda and glued with FF resin, found that shear stresses values in the boiling cycle test varied from 0.94 to $1.26 \mathrm{MPa}$. Bortoletto $\mathrm{Jr}$ (2003) obtained, for phenolic plywood panels produced from 11 Eucalyptus species, shear stresses values from 1.91 to $2.42 \mathrm{MPa}$ in the boiling cycle test. The author also observed low percentage of wood failure for the studied Eucalyptus species. Jaeger and Zeiger (2007), studying mixed plywood panels made with Eucalyptus dunnii and Pinus taeda, observed shear strengths of $2.21 \mathrm{MPa}$ in the boiling cycle test. All results obtained in this study were superior to the minimum 1.0 MPa value, independent from the percentage of wood failures, established by the European Norm EN 314-2 (1993).

\section{CONCLUSIONS}

- There was no observed significant difference between the basic specific mass of Melia azedarach and Pinus taeda woods. Melia azedarach wood presented equal or higher extractive components content when compared to Pinus taeda.

- Both with urea-formaldehyde and phenol-formaldehyde resins, the plywood panels produced with Melia azedarach veneers showed better results in static bending and in shear strength tests.

- Melia azedarach panels presented low wood failure percentage in the glue line shear tests, however, values of shear strength above 1.0 Mpa comply with the norm EN 314-2 (1993).

- Results of this study demonstrated that Melia azedarach wood presents potential for plywood panels production, both for internal (UF) and for external (FF) applications.

\section{REFERÊNCIAS}

BALDWIN, R. F. Plywood and veneer-based products: manufacturing practices. San Francisco: Miller Freeman. 1995. 388 p.

BENDSTEN, B. A. Properties of wood from improved and intensively managed tress. In: PROCEEDINGS OF THE ECONOMICS AND FINANCIAL MANAGEMENT AND TIMBER 
PRODUCTION TECHNICAL COMITEES OF THE FOREST PRODUCTS RESEARCH SOCIETY, 1978, Atlanta. Anais do... Atlanta, 1978. p. 78.

BOBADILLA, E. A. Durabilidad natural de la madera de cinco espécies aptas para La indústria de La construcción. 118 f. Dissertação (Maestria en Tecnologia de Madera, Celulosa y Papel) - Universidad Nacional de Missiones, Missiones, 2004.

BORTOLETTO JR., G.; BELINI, U. L. Produção de lâminas e manufatura de compensados a partir da madeira de guapuruvu (Schizolobium parahyba Blake) proveniente de um plantio misto de espécies nativas. Cerne, Lavras, v. 8, n. 2, p. 1 - 16, 2002.

BORTOLETTO JR, G. Produção de compensados com 11 espécies do gênero Eucalyptus, avaliação das suas propriedades físico-mecânicas e indicações para utilização. Scientia Forestalis, Piracicaba, v. 63, p. $65-78,2003$.

CASTRO, J. Caracterização da madeira de Eucalyptus grandis Hill ex. Maiden, de diferentes idades, visando a sua utilização na indústria moveleira. $160 \mathrm{f}$. Tese (Doutorado em Ciências Florestais) - Setor de Ciências Agrárias, Universidade Federal do Paraná, Curitiba, 2002.

COMISSÃO PANAMERICANA DE NORMAS TÉCNICAS. COPANT 461. Determinación del peso especifico aparente. 1972.

EUROPEAN COMMITTEE FOR STANDARDIZATION. European Standard EN 310. Determination of modulus of elasticity in bending and of bending strength. Brussels, 2002.

2004.

European Standard EN 314:1 - Plywood - Bonding-quality - Part 1: Test methods. Brussels, 2002.

European Standard EN 314-2 - Plywood - Bonding quality - Part 2: Requirements. Brussels,

IWAKIRI, S.; SILVA, J. C.; SILVA, J. R. M.; ALVES, C. R.; PUEHRINGER, C. A. Produção de compensados de Pinus taeda L.E e Pinus oocarpa Schiede com diferentes formulações de adesivo uréiaformaldeído. Árvore, Viçosa, v. 26, n. 3, p. 371 - 375, 2002.

IWAKIRI, S.; VARGAS, C. A.; PARCHEN, C. F. A.; WEBER, C.; BATISTA, C. C.; GARBE, E. A.; CIT, E. J.; PRATA, J. G. Avaliação da qualidade de painéis compensados produzidos com lâminas de madeira de Schizolobium amazonicum. Floresta, Curitiba, v. 41, n. 3, p. 451 - 458, 2011.

JAEGER, P.; ZIGER, M. Avaliação das propriedades mecânicas de painéis compensados de Eucalyptus dunnii e Eucalyptus dunnii/Pinus taeda. Cerne, Lavras, v. 13, n. 3, p. 329 - 338, 2007.

MARRA, A. A. Technology of wood bonding: principles in practice. New York: Van Nostrand Reinhold. 1992. 453 p.

MARTINEZ, S. S. O NIM - Azidirachta indica: natureza, usos múltiplos, produção. Instituto Agronômico do Paraná. Londrina: IAPAR, 142 p, 2002.

PINTO, J. A. Análise da viabilidade do uso da madeira de Cryptomeria japônica para laminação e produção de painéis compensados. 85f. Dissertação (Mestrado em Ciências Florestais) - Setor de Ciências Agrárias, Universidade Federal do Paraná, Curitiba, 2011.

SELLERS, T. Plywood and adhesive technology. New York: Marcel Dekker. 1993. 661 p.

STELlA, J. C. A influência de variáveis do ciclo de prensagem e gramatura de cola nas propriedades mecânicas de compensado de paricá (Schizolobium amazonicum). $51 \mathrm{f}$. Monografia (Graduação em Engenharia Industrial Madeireira) - Setor de Ciências Agrárias, Universidade Federal do Paraná, Curitiba, 2009.

TAPPI - TECHNICAL ASSOCIATION OF THE PULP AND PAPER INDUSTRY. 1997. TAPPI 204. Solvent extractives of wood and pulp. Atlanta. 
. TAPPI 207: Water solubility of wood and pulp. Atlanta, 1999.

. TAPPI 280: Acetone extractives of wood and pulp. Atlanta, 1999.

. TAPPI 212: One percent sodium hydroxide solubility of wood and Pulp. Atlanta, 2002.

. TAPPI 252: $\mathrm{pH}$ and electrical conductivity of hot water extracts of pulp, paper, and paperboard. Atlanta, 2002.

TRIANOSKI, R. Avaliação do potencial de espécies florestais alternativas de rápido crescimento para produção de painéis de madeira aglomerada. 260 f. Dissertação (Mestrado em Ciências Florestais) - Setor de Ciências Agrárias, Universidade Federal do Paraná, Curitiba, 2010.

TRIANOSKI, R. Avaliação da qualidade da madeira de espécies de pinus tropicais por meio de métodos convencionais e não destrutivos. 553 f. Tese (Doutorado em Ciências Florestais) - Setor de Ciências Agrárias, Universidade Federal do Paraná, Curitiba, 2012.

VIVAN, M. P. Uso do cinamomo (Melia azedarach) como alternativa aos agroquímicos no controle do carrapato bovino (Boophilus microplus). 72 f. Dissertação (Mestrado em Agroecosistemas) Universidade Federal de Santa Catarina, Florianópolis, 2005. 